\title{
TWINNING THE BRAIN WITH MACHINE LEARNING FOR NEURO-MUSCULAR EFFICIENCY (TwinBrain)
}

The project "TWINning the BRAIN with machine learning for neuro-muscular efficiency (TwinBrain) ${ }^{1}$ ", will be implemented between 1 November 2020 and 31 October 2023. The project is a part of the call "Horizon 2020 Twinning widespread-05-2020". The TwinBrain project was successfully designed and obtained within the Institute for Kinesiology Research, Science and Research Centre Koper (ZRS Koper), under the leadership of dr. Uroš Marušič. The project partners with prestigious universities from Germany (Technische Universität Berlin; TUB) and Switzerland (Université de Genève; UNIGE) and the Neurology Department of Cattinara Hospital (Università degli Studi di Trieste; UNITS, Italy). The $€ 0.9 \mathrm{M}$ project, which will last for three years, aims to establish a research and diagnostic centre in the field of neuromuscular efficiency and to understand the functioning and control of the central nervous system during movement. One specific goal of the TwinBrain project is to increase the scientific and technological capacities of related institutions with an emphasis on the institution of the applicant country - ZRS Koper.

The activities of the TwinBrain project are aimed at establishing and raising the quality of the research group in the country with a lower R\&I index (ZRS Koper), with the help of partner institutions with a higher R\&I index (TUB, UNIGE and UNITS). The ultimate goal of the project is to set up the SloMoBIL: Slovenian Mobile Brain/ Body Imaging Laboratory, which will be established through the transfer of knowledge and technology from BeMoBIL: Berlin Mobile Brain/Body Imaging Laboratory ${ }^{2}$. In order to fully understand brain dynamics in actively moving people, we need to analyse brain dynamics in relation to coincident behaviour. This combination makes it possible to assess the complex interrelationships between brain and behavioural dynamics and is captured in the Mobile Brain/Body Imaging (MoBI) system. The MoBI system aligns real-time EEG signals with concurrent recordings of eye movements, body movements, and autonomic responses. The result is the simultaneous capture of large amounts of data that require advanced methods to process. To this end, the TwinBrain project plans to implement machine learning methods that can statistically "learn" nonlinear relationships between brain dynamics and behaviour. A central aim of these analyses is to identify a limited number of functionally different large-brain networks that represents different aspects of the performed and recorded behavioural information. In that way, it would not only be possible to statically image brain activities related to the given task, but to characterise specific large-scale network dynamics and describe their time-resolved properties in relation to behaviour.

\footnotetext{
$1 \mathrm{https}: / /$ cordis.europa.eu/project/id/952401.

2 https://blogs.tu-berlin.de/bpn_bemobil/.
} 
Finally, with successful coupling of brain dynamics, motion kinematics, advanced brain imaging techniques, and machine learning, this project aims at transferring technology and knowledge among the included partners and beyond. As a result, the consortium will have enhanced scientific and technological capacity as well as networking activities. The institution from Slovenia (ZRS Koper) will raise its research profile and the research profile of its staff. Taking the broader perspective, through all proposed activities, a new and dynamic network will be established, enabling the involved partners to continue their scientific and professional collaboration, including in the framework of new EU-funded research projects, with the view of addressing wider challenges related to demographics and health.

Uroš Marušič 


\section{TWINNING THE BRAIN WITH MACHINE LEARNING FOR NEURO-MUSCULAR EFFICIENCY (TwinBrain)}

Med 1. novembrom 2020 in 31. oktobrom 2023 bodo potekale dejavnosti projekta »TWINning the BRAIN with machine learning for neuro-muscular efficiency (TwinBrain) ${ }^{3} \ll$, ki je bil pridobljen na razpisu »Horizont 2020 Twinning widespread-05-2020«. Projekt TwinBrain je bil v okviru Inštituta za kineziološke raziskave Znanstveno-raziskovalnega središča Koper (ZRS Koper) uspešno zasnovan in prijavljen pod vodstvom dr. Uroša Marušiča. Ob ZRS Koper sodelujejo v projektu kot partnerji prestižni univerzi iz Nemčije (Technische Universität Berlin; TUB) in Švice (Université de Genève; UNIGE) ter nevrološki oddelek bolnišnice Cattinara (Università degli Studi di Trieste; UNITS, Italija). Projekt v vrednosti 0,9 milijona evrov, ki bo trajal tri leta, si za cilj postavlja vzpostavitev raziskovalno-diagnostičnega centra na področju živčno-mišične učinkovitosti ter razumevanja delovanja in nadzora centralnega živčnega sistema med gibanjem. Poseben cilj projekta TwinBrain je tudi povečanje znanstvene in tehnološke zmogljivosti povezanih inštitucij, pri čemer je poudarek na inštituciji države prijaviteljice ZRS Koper.

Dejavnosti projekta TwinBrain so usmerjene v vzpostavitev in dvig kakovosti raziskovalne skupine $\mathrm{v}$ državi $\mathrm{z}$ nižjim kazalnikom raziskav in inovacij (R\&I; ZRS Koper) s pomočjo partnerskih inštitucij z višjim kazalnikom R\&I (TUB, UNIGE in UNITS). Končni cilj projekta je postavitev laboratorija SloMoBIL: Slovenian Mobile Brain/Body Imaging Laboratory, ki bo vzpostavljen prek prenosa znanj in tehnologije iz BeMoBIL: Berlin Mobile Brain/Body Imaging Laboratory ${ }^{4}$. Da bi lahko v celoti razumeli možgansko dinamiko pri aktivno premikajočih se ljudeh, moramo analizirati možgansko dinamiko v povezavi s sočasnim vedenjem. Ta kombinacija omogoča oceno zapletenih medsebojnih odnosov med možgansko in vedenjsko dinamiko in je zajeta v sistemu Mobile Brain/Body Imaging (MoBI). Ta sistem v realnem času usklajuje EEGsignale s hkratnimi posnetki gibov oči, gibov telesa in avtonomnih odzivov. Posledično gre za hkratno zajemanje velike količine podatkov, ki zahtevajo napredne metode obdelave. V ta namen v projektu TwinBrain načrtujemo uporabo metod strojnega učenja, ki se lahko statistično »naučijo« nelinearnih razmerij med možgansko dinamiko in vedenjem. Osrednji cilj teh analiz je prepoznati omejeno število funkcionalno različnih obsežnih možganskih omrežij, ki predstavljajo različne vidike izvedenih in zabeleženih vedenjskih informacij. Tako ne bi bilo mogoče le statično prikazati možganskih dejavnosti, povezanih z dano nalogo, temveč tudi opredeliti specifično dinamiko obsežnega možganskega omrežja in opisati njihove časovne lastnosti glede na vedenje.

Nazadnje je cilj tega projekta ob uspešnem povezovanju možganske dinamike, kinematike gibanja, naprednih tehnik slikanja možganov in strojnega učenja prenesti teh-

\footnotetext{
$3 \mathrm{https}: / /$ cordis.europa.eu/project/id/952401.

4 https://blogs.tu-berlin.de/bpn_bemobil/.
} 
nologije in znanja med vključene partnerje in širše. Rezultat tega bodo okrepljene znanstvene in tehnološke zmogljivosti in dejavnosti mreženja konzorcija. Vodilni partner projekta iz Slovenije (ZRS Koper) bo povečal svoj raziskovalni profil in raziskovalni profil svojega osebja. Na podlagi širše perspektive se bo z vsemi predlaganimi dejavnostmi vzpostavila nova dinamična mreža, ki bo vključenim partnerjem omogočila nadaljevanje znanstvenega in strokovnega sodelovanja tudi v okviru novih raziskovalnih projektov, ki jih financira EU, s pogledom na obravnavanje širših izzivov, povezanih z demografijo in zdravjem.

Uroš Marušič 